\title{
Analisis Faktor-Faktor Yang Mempengaruhi Return on Assets Pada Perusahaan Plastik dan Kemasan
}

\author{
Marwin Antonius Rejeki Silalahi \\ Universitas Surabaya \\ *marwin.antonius@gmail.com
}

\begin{abstract}
Abstrak
Penelitian ini bertujuan untuk melihat kinerja perusahaan plastik dan kemasan yang terdaftar di BEI. Masuknya produk plastik dan kemasan dari Cina ke Indonesia, mengakibatkan omzet penjualan perusahaan lokal menurun dari biasanya. Selain itu, penelitian ini bertujuan untuk membantu para praktisi dan investor dalam mengambil keputusan, serta untuk kalangan akademisi dapat dijadikan acuan dalam bahan penelitian selanjutnya. Penelitian ini menggunakan 10 sampel perusahaan, yang perlaporan keuangannya sebanyak empat kali dalam setahun, dengan jumlah sampel sebanyak 182 data. Penelitian ini menggunakan model regresi linier berganda, uji asumsi klasik, uji f dan uji t. Penelitian ini mengkaji Current Ratio, Total Asset Turnover, dan Debt Equity Ratio terhadap Return on Assets. Hasil penelitian ini adalah Current Ratio dan Total Asset Tunover berpengaruh signifikan terhadap Return on Assets, sedangkan Debt Equity Ratio tidak berpengaruh signifikan terhadap Return on Assets. Hal ini disebabkan sampel data dalam penelitian ini menggunakan hutang jangka pendek daripada hutang jangka panjang.
\end{abstract}

Kata Kunci: Current Ratio, Total Asset Tunover, Debt Equity Ratio, Return on Asset, asymentri information.

\section{Pendahuluan}

Perkembangan jaman yang semakin meningkat, khususnya di bidang industri plastik dan kemasan. Seperti polypropilene, polyetilene dan sejumlah produksi bahan baku plastik lainnya. Hal ini menyebabkan permintaan plastik semakin meningkat, meningkatnya permintaan plastik berdampak positif pada perusahaan industri plastik yang menyebabkan kedua perusahaan plastik lokal tersebut tumbuh dan berkembang, seiring dengan perkembangan tersebut, banyak investor mulai tertarik untuk berinvestasi di sektor industri plastik dan kemasan.

Banyak Investor dalam memilih investasinya, mereka masih mengacu pada laporan keuangan. Laporan keuangan merupakan informasi keuangan yang memuat kondisi dan aktivitas kinerja perusahaan. Aktivitas kinerja perusahaan terdiri dari aktivitas operasional, aktivitas investasi dan aktivitas pendanaan. Menurut Dictio dari blognya https://www.dictio.id/t/ menyatakan 'kegiatan operasional adalah kegiatan yang berkaitan dengan operasional perusahaan yaitu penerimaan kas dari penjualan, royalti, provisi, komisi dan pembayaran tunai kepada pemasok barang dan jasa, gaji karyawan, pembayaran pajak. Sedangkan kegiatan investasi adalah kegiatan perusahaan yang terdiri dari pembelian aktiva tetap, aktiva tidak berwujud dan aktiva tidak lancar lainnya termasuk biaya pengembangan yang 


\section{Marwin Antonius Rejeki Silalahi}

dikapitalisasi dan aktiva tetap yang dibangun sendiri'. Kemudian kegiatan pendanaan adalah kegiatan perusahaan yang terdiri dari penerimaan dan pembayaran pinjaman hutang jangka panjang dan jangka pendek, penerimaan kas dari saham (modal), pembayaran tunai kepada pemegang saham untuk menarik atau menebus saham perusahaan, penerimaan kas dari obligasi dan pembayaran tunai dengan cara bisnis penyewa (lease) untuk mengurangi saldo kewajiban yang terkait dengan sewa pembiayaan.

Untuk mengukur kinerja keuangan perusahaan diperlukan analisis laporan keuangan, analisis laporan keuangan biasanya dilakukan dengan menggunakan rasio-rasio keuangan. Rasio keuangan ini harus dibandingkan dengan laporan keuangan tahun sebelumnya, kemudian dibandingkan dengan rata-rata industri. Dalam mengukur kinerja keuangan perusahaan, dikatakan sehat atau tidak, maka benchmark dilakukan dengan penjualan, persediaan, aset, hutang, dan modal yang dimiliki perusahaan. Kelima aspek tersebut merupakan penilaian yang paling efektif untuk menilai baik tidaknya aktivitas perusahaan, serta mampu tidak membayar kewajibannya (Gunawan, 2019).

Hal ini juga berpengaruh tidak langsung terhadap keputusan pendanaan yang akan mempengaruhi struktur modal perusahaan. Menurut Kusuma (2010) dalam Prayugi dan Mardani (2019) bahwa "Kesalahan dalam penentuan struktur modal akan berdampak luas, terutama jika perusahaan terlalu besar dalam menggunakan hutang, sehingga beban tetap yang harus ditanggung oleh perusahaan semakin besar. lebih besar juga berarti akan meningkatkan risiko keuangan yaitu risiko ketika perusahaan tidak dapat membayar biaya bunga atau mencicil hutang. Struktur modal yang optimal dapat meminimalkan biaya modal rata-rata (average cost of capital) dan memaksimalkan nilai perusahaan. Hal tersebut dapat mempengaruhi kinerja perusahaan. Untuk mengukur kinerja perusahaan biasanya dilakukan dengan cara menganalisis laba, peningkatan laba akan memberikan sinyal positif tentang kinerja perusahaan di masa yang akan datang. Menurut Alpi dan Gunawan (2018) "Laba tentunya dipengaruhi oleh beberapa aspek antara lain total aset, aset lancar, kewajiban lancar, dan penjualan". Total aset adalah semua sumber daya yang dimiliki oleh perusahaan dan digunakan untuk kegiatan operasional perusahaan serta diperoleh dari aktivitas masa lalu. Semakin tinggi total aset akan meningkatkan jumlah produksi barang dan akan meningkatkan keuntungan secara tidak langsung, artinya peningkatan aset sejalan dengan peningkatan keuntungan. Sedangkan aset lancar adalah uang tunai atau simpanan yang dapat dicairkan dalam waktu singkat tidak lebih dari 1 tahun, dengan ketentuan kegiatan perusahaan berjalan normal. Aktiva lancar yang semakin meningkat ditandai dengan kegiatan operasional yang semakin meningkat dan berdampak pada peningkatan laba. Namun kasus nilai aktiva lancar yang besar juga kurang baik bagi perusahaan, karena kas atau dana likuid mengendap dan tidak diputar, akan menimbulkan biaya peluang.

Hutang lancar merupakan kewajiban perusahaan yang berlangsung dalam waktu yang singkat, hutang lancar biasanya digunakan untuk memenuhi kebutuhan operasional perusahaan. Dan pembayaran hutang saat ini harus dibayar dalam jangka pendek. Penjualan perusahaan berasal dari kegiatan operasional perusahaan, peningkatan penjualan ditandai dengan peningkatan biaya operasional, biaya operasional yang tinggi secara tidak langsung ditandai dengan peningkatan jumlah barang yang diproduksi. Oleh karena itu komponen-komponen tersebut akan mempengaruhi laba perusahaan, oleh karena itu aktivitas penjualan merupakan komponen yang sangat penting dalam mengukur kinerja perusahaan.

Berdasarkan latar belakang tersebut maka penulis menggunakan dua teori yaitu teori pecking order dan teori asimetri informasi. Teori pecking order dalam analisis struktur modal dikembangkan oleh Myers dan Majluf (1984) dalam Harjito (2011). Menurut Harjito (2011) sumber pertama modal perusahaan harus berasal dari hasil operasi perusahaan berupa laba bersih setelah pajak yang tidak dibagikan kepada pemilik atau pemegang saham perusahaan 
(laba ditahan). Seperti kita ketahui sumber pendanaan dibedakan menjadi dua yaitu eksternal dan internal. Pendanaan eksternal berasal dari pinjaman bank atau hutang pemasok, sedangkan pendanaan internal berasal dari ekuitas. sedangkan teori asimetri informasi adalah teori dimana informasi yang dimiliki oleh satu pihak dengan pihak lainnya tidak sama atau bias. Menurut Rahmawati (2006) dalam Mahawyahrti dan Budiasih (2016) menyatakan bahwa asimetri informasi dapat memicu manajemen laba. Teori keagenan menyiratkan adanya asimetri informasi antara manajer sebagai agen dan pemilik (dalam hal ini pemegang saham) sebagai prinsipal.

\section{Landasan Teori dan Pengembangan Hipotesis}

Rasio aktiva lancar merupakan rasio jangka pendek yang biasanya digunakan untuk operasional perusahaan dan sangat likuid, semakin meningkatnya rasio aktiva lancar, dapat pula diartikan bahwa perusahaan tidak mampu memuta aktiva lancar yang efisien. Rasio lancar menurut Erari (2014) adalah rasio yang digunakan untuk mengukur tingkat likuiditas. Likuiditas menunjukkan kemampuan perusahaan dalam membayar kewajiban keuangan untuk membayar kewajiban keuangan jangka pendek tepat waktu. Likuiditas perusahaan merupakan faktor penting yang harus diperhatikan sebelum mengambil keputusan untuk menentukan besarnya pengembalian saham yang harus dibayarkan (Riyanto, 2008 dalam Erari 2014). ditambah argumennya menurut Murhadi (2013) dalam Alpi dan Gunawan (2018) menyatakan "Rasio lancar adalah rasio yang digunakan untuk mengukur kemampuan perusahaan dalam memenuhi kewajiban jangka pendek (solvabilitas jangka pendek) yang akan jatuh tempo dalam satu tahun". Untuk alasan ini, peneliti tertarik untuk mengembangkan hipotesis mengenai perusahaan plastik dan kemasan, yang berarti rasio lancar berpengaruh terhadap pengembalian aset.

H1: Current Ratio berpengaruh signifikan terhadap Return On Assets.

Menurut Supardi et al (2016) perputaran total aset ini menunjukkan modal kerja, hubungan modal kerja dengan penjualan, serta total penjualan yang diperoleh dari masingmasing unit usaha untuk setiap rupiah modal kerja. Hasil penelitian Afriyanti (2011), Ni Made Veronika, dan Barus (2013) dalam Supardi et al (2016) menyatakan bahwa total asset turnover berpengaruh terhadap asset return. Begitu pula menurut Murhadi (2013) yang menyatakan dalam Alpi dan Gunawan (2018) Total Asset Turnover (TATO) adalah efektifitas perubahan dalam menggunakan asetnya untuk menciptakan pendapatan. Menurut Margaretha (2011) dalam Alpi dan Gunawan (2018), Total Asset Turnover merupakan rasio yang menunjukkan keefektifan suatu perusahaan dalam menggunakan seluruh asetnya untuk menciptakan penjualan dan menghasilkan keuntungan. Untuk alasan ini, peneliti tertarik untuk mengembangkan hipotesis mengenai perusahaan plastik dan kemasan, yang berarti total efek perputaran aset terhadap pengembalian aset.

H2: Total Asset Turnover berpengaruh signifikan terhadap Return On Asset.

Hutang diartikan sebagai semua kewajiban perusahaan untuk membayar sejumlah uang / jasa / barang di masa depan kepada pihak lain, akibat transaksi yang dilakukan di masa lalu (Rudianto (2008): dalam Prasetyo et al. (2015)), sedangkan Menurut Munawir (2007) dalam Sufiyati (2016) mengemukakan bahwa hutang adalah semua kewajiban keuangan perusahaan kepada pihak lain yang belum terpenuhi, dimana hutang ini merupakan sumber dana atau modal perusahaan yang berasal dari kreditur. Nurwahyudi dan Mardiyah (2004) dalam Sufiyati (2016) mengemukakan bahwa hutang merupakan pengorbanan ekonomi yang harus dilakukan oleh perusahaan dimasa yang akan datang karena tindakan atau transaksi sebelumnya. Sedangkan menurut Sutrisno (2009) dalam Sufiyati (2016) hutang adalah modal yang bersumber dari pinjaman, baik dari bank, lembaga keuangan, maupun dengan menerbitkan surat utang, dan 
untuk penggunaan tersebut perusahaan memberikan kompensasi berupa bunga tetap kepada perusahaan. Untuk alasan ini, peneliti tertarik untuk mengembangkan hipotesis mengenai perusahaan plastik dan kemasan, yang berarti rasio ekuitas hutang berpengaruh terhadap pengembalian aset.

H3: Debt Equity Ratio berpengaruh signifikan terhadap Return On Asset.

\section{Metode Penelitian}

Bentuk penelitian dari penelitian ini adalah penelitian kausalitas, karena penelitian ini dilakukan untuk menguji pengaruh variabel independen (current ratio, total asset turnover, dan debt equity ratio) terhadap variabel dependen (return on asset). Subjek dalam penelitian ini adalah perusahaan plastik dan kemasan yang terdaftar di Bursa Efek Indonesia tahun 2012 2018. Populasi dalam penelitian ini adalah perusahaan plastik dan kemasan yang terdaftar di Bursa Efek Indonesia. Dari populasi yang tersedia, jumlahnya

Sampel yang akan diamati adalah perusahaan plastik dan kemasan dari tahun 2012 hingga 2018. Sampel dipilih dengan menggunakan metode Purposive Sampling, yaitu suatu teknik yang sengaja mengambil sampel tertentu sesuai dengan kebutuhan yang dibutuhkan yang meliputi: karakteristik dan sampel kriteria khususnya, dimana dalam hal pengambilan sampel juga harus mencerminkan populasi sampel itu sendiri (Cooper dan Schlinder, 2014). Oleh karena itu, dengan memperhatikan permasalahan dan tujuan penelitian yang ada maka kriteria perusahaan yang dapat dijadikan sampel adalah sebagai berikut:

1. Perusahaan plastik dan kemasan yang terdaftar di Bursa Efek Indonesia dari tahun 2012 hingga 2018.

2. Perusahaan plastik dan kemasan yang terdaftar di Bursa Efek Indonesia dilaporkan setiap triwulan selama periode penelitian.

Instrumen dalam penelitian ini dilakukan dengan bantuan program SPSS. Pengujian hipotesis dilakukan setelah model regresi linier berganda. Hal ini dimaksudkan agar hasil perhitungan tersebut dapat diinterpretasikan secara tepat dan efisien. Interpretasi parsial hasil penelitian (uji t) hanya dilakukan terhadap variabel independen yang memiliki pengaruh signifikan secara statistik terhadap variabel independen.

Data yang digunakan dalam penelitian ini adalah data sekunder, yaitu informasi yang diperoleh dari pihak lain. Data yang dibutuhkan dalam penelitian ini adalah laporan keuangan perusahaan non keuangan tahun 2012 sampai dengan 2018 yang terdaftar di Bursa Efek Indonesia. Data dalam penelitian ini diperoleh dari website BEI dan aplikasi RHB Securities. Instrumen dalam penelitian ini dilakukan dengan bantuan program SPSS. Sebelum menguji hipotesis terlebih dahulu menguji asumsi klasik yang di dalamnya terdapat uji normalitas, uji multikolinieritas, uji heteroskedastisitas dan uji autokorelasi. Hal ini agar hasil perhitungan tersebut dapat diinterpretasikan dengan tepat dan efisien. Setelah itu peneliti melakukan uji regresi berganda yang terdiri dari interpretasi parsial hasil penelitian (uji t) hanya dilakukan terhadap variabel bebas yang secara statistik berpengaruh signifikan terhadap variabel bebas.

\section{Variabel Penelitian}

Menurut Margaretha (2011) dalam Alpi dan Gunawan (2018) menyatakan Rumus untuk menghitung Current Ratio (CR) yakni :

Current Ratio $(C R)=\frac{\text { Current Asset }}{\text { Current Liabilities }}$


Menurut Kasmir (2012) dalam Alpi dan Gunawan (2018) menyatakan rumus untuk mencari Total Assets Turnover (TATO) adalah sebagai berikut :

Total Assets Turnover $($ TATO $)=\frac{\text { Penjualan }}{\text { Total Aktiva }}$

Berdasarkan Ahmad et al (2012) dalam Sufiyati (2016) proporsi Total Debt dihitung dengan membagi utang jangka panjang terhadap total modal perusahaan yang dapat dirumuskan sebagai berikut:

Debt Ratio $(D R)=$ Total Debt

Total Equity

Menurut Kasmir 2012 dalam Alpi dan Gunawan (2018) menyatakan Rumus untuk mencari Return On Assets (ROA) dapat digunakan sebagai berikut :

Return on Asset $(R O A)=$ Laba Setelah Pajak

Total Aktiva

\section{Pembahasan}

Populasi data yang digunakan dalam penelitian ini adalah seluruh perusahaan plastik dan kemasan yang terdaftar di Bursa Efek Indonesia tahun 2012 sampai dengan 2018. Sampel yang digunakan dalam penelitian ini adalah 10 perusahaan plastik dan kemasan yang terdaftar di Bursa Efek Indonesia dan menerbitkan laporan keuangannya setiap empat bulan. sekali. dalam 1 tahun. Populasi sampel dalam penelitian ini diperoleh sebanyak 364 sampel, dari 364 sampel diperoleh 84 sampel tidak mempublikasikan laporan keuangan secara triwulanan, kemudian setelah itu dilakukan uji normalitas dan ditemukan 98 sampel yang tidak normal. Jadi sampel data yang dapat digunakan dalam penelitian ini sebanyak 182 sampel.

Tabel 1

Uji Test Normalitas

\begin{tabular}{|c|c|c|c|}
\hline & \multicolumn{3}{|c|}{ Kolmogorov-Smirnov $^{a}$} \\
\hline & Statistik & df & Sig. \\
\hline Ln_CR &, 225 & 182 &, 051 \\
\hline Ln_Tot &, 091 & 182 &, 077 \\
\hline Ln_DER &, 097 & 182 &, 080 \\
\hline Ln_ROA &, 045 & 182 &, 200 \\
\hline
\end{tabular}

Sumber: SPSS data Versi 22

Berdasarkan Tabel 1 hasil Uji Normalitas untuk masing-masing variabel current ratio, total asset turnover, debt equity ratio, dan return on asset mempunyai nilai signifikan>0,05 yang artinya semua variabel berdistribusi normal. 
Tabel 2

Uji Test Multikolinearitas

\begin{tabular}{|c|c|}
\hline \multicolumn{2}{|c|}{ Colinearity Statistics } \\
\hline Tolerance & VIF \\
\hline, 523 & 1,014 \\
\hline, 986 & 1,014 \\
\hline, 820 & 1,922 \\
\hline
\end{tabular}

Sumber: SPSS data Versi 22

Berdasarkan tabel di atas untuk uji multikolinieritas didapatkan nilai toleransi yang rendah dan nilai VIF > 1 yang berarti dalam penelitian ini tidak terdapat uji multikolinieritas yang menunjukkan tidak terdapat korelasi antar variabel.

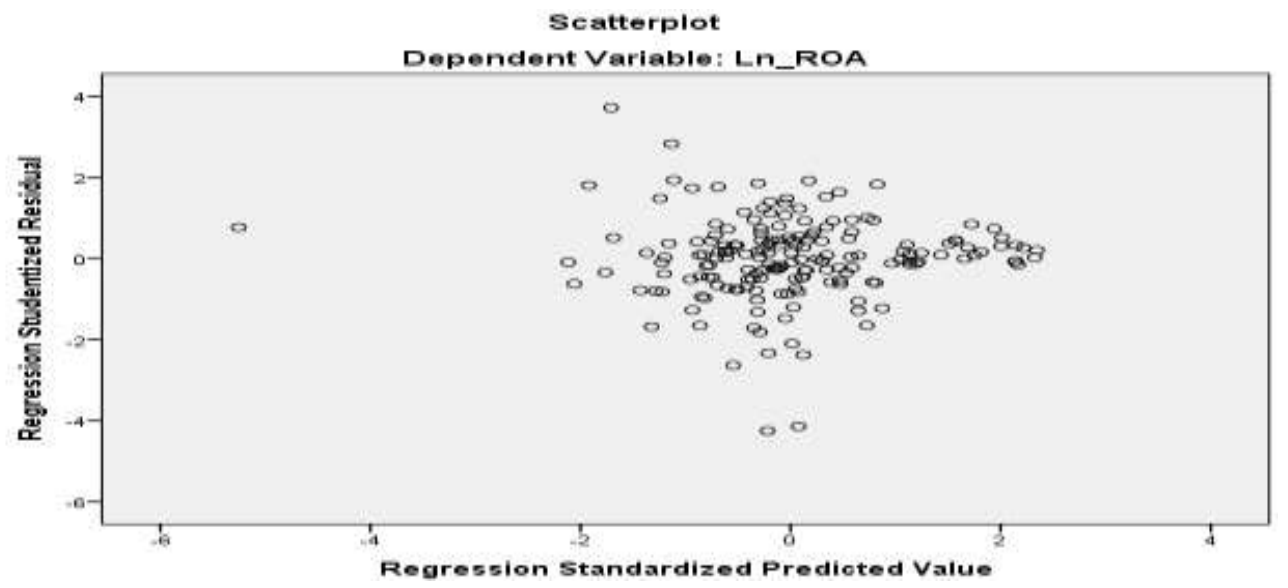

Gambar 1. Uji Test Heteroskedastisitas

Sumber: SPSS data Versi 22

Pada penelitian ini untuk menguji heteroskedastisitas menggunakan scater plot, dimana hasil penelitian menunjukkan tidak terdapat pola yang spesifik yang artinya tidak terjadi setiap varial dependent dan independent tidak terjadi heteroskedastisitas yang artinya setiap variabel dalam penelitian ini tidak terjadi ketidaknyamanan antar varians. antar variable.

Tabel 3

Uji Test Autokorelasi

\begin{tabular}{|c|c|}
\hline & Unstandardized Residual \\
\hline Test Value &, 02560 \\
\hline Cases $<$ Test Value & 91 \\
\hline Cases $>$ Test Value & 91 \\
\hline Total Cases & 182 \\
\hline Number of Runs & 74 \\
\hline Z & $-2,676$ \\
\hline Asymp.Sig. (2-tailed) &, 077 \\
\hline
\end{tabular}

Sumber: SPSS data Versi 22

Uji autokorelasi untuk melihat apakah model regresi baik untuk penelitian atau tidak, atau data yang digunakan dalam penelitian ini bersifat acak atau tidak. Berdasarkan hasil penelitian diperoleh nilai signifikansi diatas 0.05 yang berarti model regresi dalam penelitian ini tidak mengalami autokorelasi. 

dilampirkan:

Penelitian ini menggunakan model regresi linier berganda, model penelitian berikut

$$
\mathrm{Y}=-4,298+0,988 \mathrm{X} 1+0,691 \mathrm{X} 2+0,249 \mathrm{X} 3+\mathrm{e}
$$

Informasi:

$\mathrm{Y}=$ Pengembalian Aset

$\alpha=$ Konstanta: - 4,298 menunjukkan bahwa variabel current ratio, total asset turnover dan debt ratio, jika nilainya 0 maka return on asset akan turun sebesar - 4,298

$\beta 1-\beta 3=$ Regresi Koefisien: Nilai koefisien CR $(\beta 1)$ adalah 0,988 dengan nilai positif nilai. Artinya untuk setiap kenaikan Current Ratio sebanyak 1 kali, Return on Assets (ROA) akan meningkat sebesar 0.988 dengan asumsi variabel lainnya konstan. Koefisien TOT ( $\beta 2)$ adalah 0,691 dengan nilai positif. Artinya untuk setiap kenaikan Total Asset Tunover sebanyak 1 kali, Return on Asset (ROA) akan meningkat sebesar 0.691 dengan asumsi variabel lainnya konstan. Nilai koefisien DER ( $\beta 3$ ) sebesar 0,249 dengan nilai positif. Artinya untuk setiap 1 kali kenaikan Debt Equity Ratio, Return on Assets (ROA) akan meningkat sebesar 0,249 dengan asumsi variabel lain konstan.

$\mathrm{X} 1=$ Current Ratio

$\mathrm{X} 2=$ Total Asset Turnover

$\mathrm{X} 3=$ Debt Equity Ratio

e $\quad=$ Kesalahan standar

\section{Tabel 4}

Uji t

\begin{tabular}{|c|c|c|c|c|c|}
\hline & \multicolumn{2}{|c|}{ Unstandardized Coefisients } & $\begin{array}{c}\text { Standardized } \\
\text { Coeficients }\end{array}$ & t & Sig \\
\hline & $B$ & Std. Error & Beta & & \\
\hline (Constant) & $-4,298$ &, 095 & & $-45,052$ &, 000 \\
\hline Ln_CR &, 988 &, 135 &, 538 & 7,299 &, 000 \\
\hline Ln_Tot &, 691 &, 073 &, 505 & 9,406 &, 000 \\
\hline Ln_DER &, 249 &, 132 &, 139 & 1,888 &, 061 \\
\hline
\end{tabular}

Sumber: SPSS data Versi 22

Berdasarkan tabel 4 diperoleh hasil uji t, variabel current ratio dan total asset turnover nilai signifikansi dibawah 0,05 yang berarti variabel current ratio dan total asset turnover berpengaruh terhadap variabel return on asset. Sedangkan nilai signifikansi debt equity ratio berada di atas 0,05 yang artinya variabel debt equity ratio tidak berpengaruh terhadap return on asset.

Tabel 5

Uji F

\begin{tabular}{|c|c|c|c|c|c|}
\hline & $\begin{array}{c}\text { Sum of } \\
\text { Squares }\end{array}$ & df & Mean Square & F & Sig \\
\hline Regression & 129,119 & 3 & 43,040 & 58,141 &, 000 \\
\hline Residual & 131,768 & 178 &, 740 & & \\
\hline Total & 260,887 & 181 & & & \\
\hline
\end{tabular}

Sumber: SPSS data Versi 22 
Berdasarkan tabel 5, hasil uji f diperoleh nilai signifikansi dibawah 0,05 yang artinya variabel current ratio, total asset turnover dan debt equity ratio (independen) secara bersamasama berpengaruh terhadap variabel return on asset (dependen).

\section{Hubungan Current Ratio (CR) dengan Return on Assets (ROA).}

Hasil uji regresi menunjukkan bahwa hipotesis pertama, Current Ratio (CR) berpengaruh signifikan terhadap Return on Assets (ROA), hal ini menunjukkan semakin besar Current Ratio maka semakin besar pula Return on Assets. Hasil penelitian ini sebelumnya didukung oleh Elyas Setiawan (2015) dalam Alpi dan Gunawan (2018) dengan judul Pengaruh Current Ratios, Inventory Turnover, Debt to Equity Ratio, Total Asset Turnover, Penjualan, dan Ukuran Perusahaan Terhadap ROA dalam Terdaftar. Perusahaan Makanan dan Minuman di Bursa Efek Indonesia (BEI) periode 2010-2013. Hasil penelitian juga sama dengan penelitian Alpi dan Gunawan (2018) yang menyatakan bahwa Current Ratio (CR) berpengaruh signifikan terhadap Return on Assets (ROA), hal ini berarti tinggi rendahnya Current Ratio (CR) akan mempengaruhi Return On Asset (ROA). Begitu pula dengan penelitian yang dilakukan saat ini memiliki hasil yang sama dimana Current Ratio (CR) berpengaruh signifikan terhadap Return on Assets (ROA). Logikanya, menurut peneliti Rasio Lancar pasti sangat berpengaruh terhadap Return on Asset, karena di dalam current ratio sendiri terdapat aktiva lancar yang menjadi bagian dari total aktiva, jadi faktor inilah yang menjadi penghubungnya.

\section{Hubungan Total Asset Turnover (TOT) dengan Return on Assets (ROA).}

Hasil uji regresi menunjukkan bahwa hipotesis kedua, Total Asset Turnover (TOT) berpengaruh signifikan terhadap Return on Assets (ROA), hal ini menunjukkan semakin besar Total Asset Turnover maka semakin besar pula Return on Assets. Berdasarkan teori penelitian sebelumnya oleh Wilhelmina (2017) dalam Alpi dan Gunawan (2018) dengan judul Pengaruh Current Ratio (CR) dan Total Asset Turnover (TATO) terhadap Return on Assets (ROA) pada PT. Pos Indonesia (Persero). Begitu pula dengan penelitian Alfin dan Gunawan (2018) dimana hasilnya sama yaitu Total Asset Turnover (TATO) berpengaruh signifikan terhadap Return On Assets (ROA), hal ini menunjukkan bahwa tinggi rendahnya Total Turnover Assets akan mempengaruhi Return On Assets perusahaan. (ROA). Penelitian saat ini juga menyimpulkan bahwa Current Ratio (CR) dan Total Asset Turnover (TATO) berpengaruh signifikan terhadap Return on Assets (ROA). Menurut peneliti, TATO pasti mempengaruhi ROA, karena TATO merupakan bagian dari ROA, dimana kedua komponen tersebut secara bersama-sama melibatkan total aset.

\section{Hubungan Debt Equity Ratio (DER) dengan Return on Assets (ROA).}

Hasil uji regresi menunjukkan bahwa hipotesis ketiga Debt Equity Ratio (DER) tidak berpengaruh signifikan terhadap Return on Assets (ROA), hal ini menunjukkan bahwa semakin besar Debt Equity Ratio (DER) maka tidak akan berpengaruh terhadap Return on Assets (ROA). Menurut Sufiyati (2016) tidak terdapat pengaruh Debt Equity Ratio (DER) terhadap Return On Asset (ROA) karena bunga hutang jangka pendek yang rendah, sehingga hutang jangka pendek berpengaruh kecil terhadap usaha penerimaan. Peneliti juga berpendapat bahwa jika komponen hutang yang digunakan bukan untuk menambah aset perusahaan, maka cenderung dapat menggunakan operasional perusahaan, sehingga DER tidak akan mempengaruhi ROA. 
INOBIS: Jurnal Inovasi Bisnis dan Manajemen Indonesia

Volume 04, Nomor 01, Desember 2020

Marwin Antonius Rejeki Silalahi

\section{Kesimpulan}

Secara parsial kesimpulan penelitian ini adalah Current Ratio dan Total Asset Turnover berpengaruh terhadap Return on Asset. Hasil penelitian ini menunjukkan bahwa peningkatan Current Ratio dan Total Asset Turnover akan meningkatkan kinerja perusahaan. Hal ini menandakan bahwa semakin meningkatnya pembelian aset perusahaan, maka akan meningkatkan produksi dan penjualan perusahaan secara langsung. Sedangkan Debt Equity Ratio tidak berpengaruh terhadap Return on Asset, karna komponen yang digunakan adalah hutang jangka pendek. Dimana hutang jangka pendek tidak digunakan untuk pembelian aset, sehingga tidak akan mempengaruhi kinerja produksi dan penjualan secara langsung.

\section{Daftar Pustaka}

Alpi FM, Gunawan Ade. 2018. Pengaruh Current Ratio dan Total Assets Turnover Terhadap Return On Assets Pada Perusahaan Plastik Dan Kemasan. Jurnal Riset Akuntansi. 17(2): $1-36$.

Andriasari WS, Miyasto, Mawardi W. 2016. Analisis Pengaruh Kebijakan Hutang, Pertumbuhan Penjualan (Growth Sales) Dan Return On Asset (ROA) Terhadap Return Saham Dengan Return On Equity (ROE) Sebagai Variabel Intervening (Studi pada Perusahaan Manufaktur yang Terdaftar di BEI Tahun 2010-2014).Jurnal Bisnis Strategi. 25(2): 135-151.

Brigham, Eugene, F., and Houston, J.F. 2010. Dasar-dasar Manajemen Keuangan (Essential of Financial Management). Edisi ke sebelas,buku 1. Terjemahan oleh Ali Akbar Yulianto. Jakarta: Salemba Empat.

Dictio.id. (2020, 1 november). Apa yang dimaksud dengan Aktivitas Operasi?. Diakses pada 1 November 2020, dari https://www.dictio.id/t/apa-yang-dimaksud-dengan-aktivitasoperasi/13946.

Erari, Anita. 2014. Analisis Pengaruh Current Ratio, Debt to Equity Ratio, dan Return On Asset Terhadap Return Saham Pada Perusahaan Pertambangan di Bursa Efek Indonesia. Program Studi Manajemen Fakulatas Ekonomi Universitas Cenderawasih. Vol.5 No.2:174-191.

Ghozali, Imam. 2016. Aplikasi Analisis Multivariate Dengan Program SPSS. Semarang: Universitas Diponegoro.

Gunawan, Ade. 2019. Analisis Kinerja Keuangan Pada Perusahaan Plastik dan Kemasan Yang Terdaftar Di Bursa Efek Indonesia. Jurnal Kumpulan Riset Akuntansi.10(2):109-115.

Jefriansyah. 2015. Pengaruh Kebijakan Hutang Dan Manajemen Laba Terhadap Nilai Perusahaan. Jurnal Ilmiah Universitas Negeri Padang, 1-21.

Kalia, 2013, Pengaruh Penggunaan Hutang terhadap Profitabilitas: Studi pada PT Semen Gresik

Tbk. Jurnal Ilmu dan Riset Manajemen, Volume 1 No. 1, Sekolah Tinggi Ilmu Ekonomi Indonesia, Surabaya.

Mahawyahrti, T Putu dan I Gusti Ayu Nyoman Budiasih. 2016. Asimetri Informasi, Leverage, dan Ukuran Perusahaan Pada Manajemen Laba. Jurnal Ilmiah Akuntansi dan Bisnis, Vol. 11, No. 2: 100-110.

Pitriana M, Chaidir. 2017. Faktor-Faktor Pengaruh Return On Investment. Jurnal Ilmiah Manajemen Fakultas Ekonomi.3(2): 60-69.

Prasetyo Yohan, Wijaya LI, Sutejo BS. 2015. Effect of Payble To Profitability In Sector Company Infrastructure, Utilities, And Transportation In IDX Period 2010 - 2014. Jurnal Manajemen \& Bisnis. 14(2): 211-218.

Sufiyati, Athinh. 2016. Analisis Pengaruh Kebijakan Utang Terhadap Kinerja Keuangan Perusahaan. Yogyakarta: Universitas Negeri Yogyakarta. 
INOBIS: Jurnal Inovasi Bisnis dan Manajemen Indonesia

Volume 04, Nomor 01, Desember 2020

Marwin Antonius Rejeki Silalahi

Supardi, Herman, H. Suratno dan Suyanto. 2016. Pengaruh Current Ratio, Debt To Asset Ratio, Total Asset Turnover Dan Inflasi Terhadap Return On Asset. Jurnal Ilmiah Akuntansi Fakultas Ekonomi. Volume 2 No. 2: 16-27.

Harjito, Agus D. 2011. Teori Pecking Order Dan Trade-Off Dalam Analisis Struktur Modal Di Bursa Efek Indonesia. Jurnal Siasat Bisnis. 15(2): 187-196. 